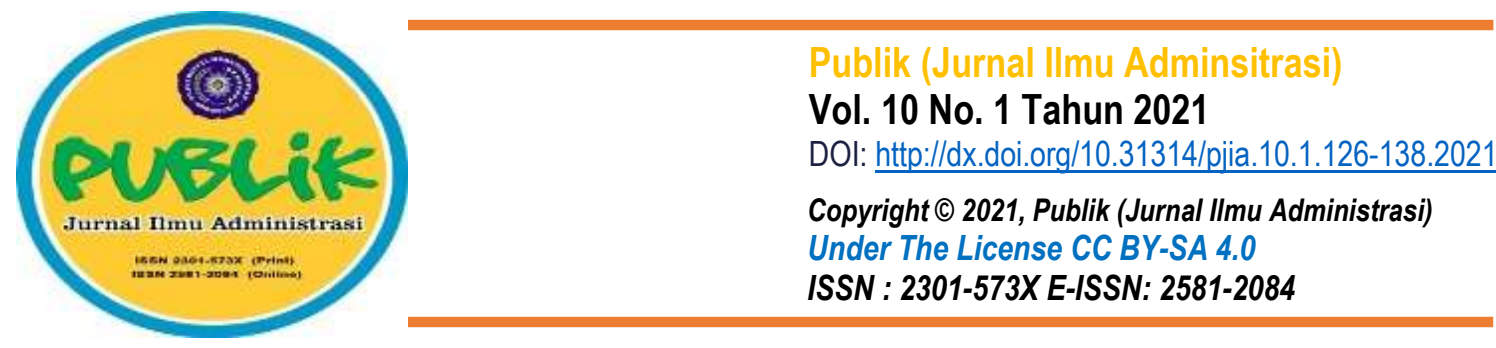

\title{
Policy Implementation Direct Cash Assistance Program in Corona Virus Disease (COVID-19) in Tondegesan Village Kawangkoan Sub District
}

\author{
Fitri H. Mamonto ${ }^{*}$, Thelma Wawointana ${ }^{2}$, Gloria Ervinsky Moningka ${ }^{3}$ \\ 1²3Universitas Negeri Manado, Indonesia \\ Email: fitrimamonto@unima.ac.id, thelmawawointana@unima.ac.id, gervinsky18@gmail.com
}

\begin{abstract}
This research aims at how the Village Fund Direct Cash Unity program in the 2019 Corona Dessease Virus pandemic (Covid-19) In Tondegesan Village, Kawangkoan District, this research uses a qualitative approach method, and uses data techniques: observation, interviews and documentation, with data sources are : The Tondegesan Village Government and the Tondegesan Village Community, with the results of the research showing 1). The standards and targets that defined the criteria set did not qualify as BLT-DD recipients. 2) Characteristics of Implementers related to the nature and tendency of implementers in the distribution of BLT-DD to go through various stages carried out through village meetings 3) The communication between the village government and the community is due to the absence of socialization from the village government regarding the BLT-DD program. For request 1) Need to be implemented as much as possible with existing standards and the right target. 2) The village government must be more objective in determining the beneficiary families of BLT-DD according to the established criteria. 3) Communication is needed in creating a harmonious relationship.
\end{abstract}

Keywords: Public Policy; Implementation; Covid-19

\section{Received:03-05-2021 Revised:03-06-2021 Accepted:08-06-2021}

\section{INTRODUCTION}

The spread of the Corona Virus Disease 2019 (Covid-19) is rapidly increasing and spreading. The World Health Organization (WHO) or the World Health Organization claimed Covid19 was a global pandemic because it caused of the million's victims, with an increasingly widespread throughout the world, so it became a very serious challenge for the government to overcome this global pandemic. This problem is both in terms of the causes and even the effects The spread of the Corona virus disease 2019 (Covid-19) outbreak throughout Indonesia which has spread to all aspects of life in the health sector, the national economy. One example of the impact on the lower classes of society who do not have a steady income and job. The impact of the 2019 Corona virus disease (Covid-19) is that many companies or businesses have terminated employment, which will certainly become a problem or cause the Indonesian economy to be considered concerned, namely a sharp decline in household consumption due to the global 
pandemic. Seeing from the problems that hit the Indonesia, the government issued social programs to help the community.

Indonesian Central Statistics Agency (bps.go.id) in September 2019 The poverty rate in Indonesia which reached 24.79 million people increased by $0.56 \%$ in March 2020 the poverty rate in Indonesia to 26.42 million people, with this percentage of the poor population in March 2020 rose to $9.78 \%$ (Central Bureau of Statistics Indonesia, 2020). Source from the Central Statistics Agency, money.kompas.com, accessed Monday, August 24, 2020, the impact of the Corona virus disease 2019 (Covid-19) which was only recorded in March 2020 from the Indonesian BPS survey showed that almost all regions experienced an increase, from 34 provinces 22 of them experienced an increase. increase in poverty. By looking at the increasing poverty rate because of the Corona virus disease 2019 (Covid-19) so that the government carries out social programs for the poor and communities affected by the Corona virus disease 2019 (Covid-19), the government's goal is that social assistance programs can be implemented. good impact and in accordance with the expected goals (Akib \& Risfaisal, 2015)

One of the programs issued by the government is the Village Fund Direct Cash Assistance (BLT-DD) program designed by the Ministry of Social Affairs for the poor and for people affected by the 2019 Corona virus disease (Covid-19), with the Village Fund Direct Assistance (Cash Assistance for Village Funds). BLT-DD) if it can help the community. The programs carried out by the government will all be distributed throughout Indonesia and then will be given to the poor and people who are directly or indirectly affected, said the President of the Republic of Indonesia, Ir. H. Joko Widodo in his speech the government will provide assistance which will later be received for families affected by the Corona virus disease 2019 (Covid-19) and to the poor, with cash amounting to Rp600,000 for the first 3 months of April, May, June then extended until December 2020 which in the following months was changed to Rp.300,000 because there was an extension of time for BLT-DD beneficiary families and will continue to receive a supply of aid funds from the government.

In a statement from the Minister of Villages, Development of Disadvantaged Regions and Transmigration, Abdul Halim Iskandar, quoted from kompas.com, said that the period for receiving Village Fund Cash Direct Assistance would be extended in accordance with the President's decision, in which the first 3 months of Village Fund Cash Assistance received Rp. April, May, and June will be added for the next 3 months, namely July, August, until December 2020 and the value will be IDR 300,000 per month. The funds used for the Village Fund Direct Cash Assistance (BLTDD) sourced from the Village Fund have been channeled to the village treasury account, and the 
BLT-DD is also listed in the APBDesa as a program or activity funded by the Village Fund (Arumdani, dkk, 2021)

Village Fund sourced from the State Revenue and Expenditure Budget (APBN) which is intended for villages, to finance government administration, development implementation, community development, and village community empowerment. That the 2020 State Budget should not be postponed in urgent circumstances in handling the 2019 Corona virus disease (Covid-19) in the Regulation of the Minister of Finance of the Republic of Indonesia Number 43/PMK 05/2020) concerning the Mechanism for the Implementation of the Expenditure Budget on the Burden of the State Revenue and Expenditure Budget in Handling the 2019 Corona virus disease (Covid-19) pandemic. That the focus of the 2020 APBN distribution is for handling the 2019 Corona virus disease (Covid-19).

The Regulation of the Minister of Villages and Development of Disadvantaged Regions and Transmigration (Permendes PDTT) number 7 of 2020 the second amendment to the regulation of the minister of village, development of disadvantaged areas, and transmigration number 11 of 2019 concerning the priority of using village funds in 2020. In Article 8A Paragraph 2, handling the impact of the Corona virus disease 2019 (Covid-19) pandemic can be in the form of Village Fund Direct Cash Assistance (BLT-DD) to poor families in the Village in accordance with the provisions of the legislation in paragraph (3) explaining poor families as referred to in paragraph (2) Those who receive Village Fund Direct Cash Assistance (BLT-DD) are families who have lost their livelihoods or jobs, have not been recorded as receiving hopeful family programs, non-cash food assistance, cash social assistance and pre-employment cards, and have family members who are vulnerable to chronic/chronic illness. (Dewi \& Andrianus, 2021).

But what is meant by poor families is not based on the Decree of the Minister of Social Affairs of the Republic of Indonesia Number: 146 / HUK / 2013 concerning Determination of Criteria and Data Collection for the Poor and Poor People, consisting of 14 poverty criteria according to the Ministry of Social Affairs of the Republic of Indonesia (Finahari, 2017). Distribution of Village Fund Direct Cash Assistance (BLT-DD) for handling the impact of the Corona virus disease 2019 (Covid19). And the priority for distributing BLT-DD Covid 19 has 4 main criteria, namely:

1. Poor families who do not get other assistance programs from the government such as PKH, BPNT, BST and others who are domiciled in the village concerned, as well as poor people according to the indicators, namely those who earn less than Rp. 600,000 per month

2. Those who have chronic chronic disease. (Which is based on legislation).

3. Those who have chronic chronic disease. (Which is based on legislation). 
With the Village Fund BLT budget, the government hopes that this budget can help the national economic recovery, and then according to the Minister of Finance Sri Mulyani Indrawati reported from kompas.com explaining that there will be changes in the amount of cash assistance and BLT received by the community from $\mathrm{Rp}$. the first month and became IDR 300,000 in the next 3 months due to the extension of the social assistance grant from April to September.

The purpose of this BLT-DD is to help people affected by the Corona virus disease 2019 (Covid-19), as well as help the poor, which then also helps the stability of the Indonesian economy, which has sharply declined in household consumption, it is hoped that with the Direct Cash Assistance program. The Village Fund (BLT-DD) can help with the problems that exist in the midst of the 2019 Corona virus disease (Covid-19) pandemic.

Based on initial observations made by the researchers themselves for families who received assistance from the government, namely the Village Fund Direct Cash Assistance (BLTDD) program. In the Distribution of the BLT-DD Program in Tondegesan Village, Kawangkoan District, there are problems related to the implementation of program distribution, which is not right on target. BLT-DD Because it did not meet the existing requirements, in conducting field observations I found that the target was not precisely targeted at the beneficiary families (KPM) because they belonged to a family that could afford it and had a steady job and income and had absolutely no impact due to the 2019 corona virus disease ( covid-19) even from this picture, it can be seen that a permanent concrete house also has vehicle assets, which clearly do not meet the criteria according to the policy according to the criteria for poor families (Arumdani, dkk, 2021) Not only that, but even village officials should also not deserve to receive direct cash assistance from the government, because they have allowances and fixed income that is budgeted in the APBDesa sourced from the Village Fund Budget (ADD) (In Government Regulation No. 11 of 2019 concerning the second amendment to Government Regulations). Number 43 of 2014 concerning implementing regulations of Law Number 6 of 2014 concerning Villages). However, in observations in Tondegesan Village, there are Village Apparatuses who receive Village Fund Cash Direct Assistance from the government which should not have received Village Consultative Council Cash Direct Assistance for Village Funds BLT-DD). Previous research concerning cash transfers has been conducted by: B. Iping with the title: Social protection through Direct Assistance program policies Cash (BLT) This study aims to analyze social protection policies in Indonesia, social protection through the provision of BLT during the COVID-19 pandemic and the impact from an economic and social perspective; $\mathrm{H}$. Iqbal with the title: Research on the Implementation of the 2008 Cash Transfer Program Policy in Kudus Regency aims to describe the implementation of the 
BLT program policy and analyze the factors that support and hinder its success; R. Dewi, HF Andrianus with the title: Analysis of the Effect of Direct Aid Policy Cash (BLT) Against Poverty in Indonesia Period 2005-2015 This study aims to examine how the implementation of BLT (Direct Cash Assistance) policies in Indonesia, how to analyze the influence of BLT policies in dealing with poverty in Indonesia and how to evaluate BLT policies in Indonesia in the 2005 period - 2015

Meanwhile, the current research emphasizes on the implementation of the Cash Social Assistance Program Policy in the midst of the 2019 Corona virus disease (covid-19) pandemic in Tondegesan Village, Kawangkoan District, because after observing the implementation of the BLT policy in Tondegesan Village it has not been in accordance with operational standards for implementation.

\section{METHODS}

The research method used in this study is a qualitative research method. The research method used, the researcher considers good and can help researchers to find out and analyze more deeply with appreciation of the problems regarding the Implementation of the Village Fund Direct Cash Assistance Program (BLT-DD) in the midst of the 2019 corona virus pandemic in Tondegesan Satu Village, Kawangkoan District.

This research focuses on several indicators of the focus of the research, including: (1) Standards and policy targets are standards which mean that the BLT-DD program has existing requirements in the distribution or provisions that have been set, with the intended target being the Tondelesan village community as beneficiaries of BLT-DD (2) Characteristics of the implementor, which means the characteristics of the implementor, how the village apparatus works in implementing the BLT-DD program in Tondegesan village (3) Communication of policies, communication is an important thing in carrying out the policy, in this study the purpose of this research is to with communication between policy actors or implementers with the policy target, namely the BLT-DD beneficiary families. The research location which is the focus of the research is located in Tondegesan Village in Kawangkoan District.

Researchers went directly to the field to collect data through observation and in-depth interviews with informants consisting of 1 village head, 1 village secretary, 5 community members and 1 village apparatus. The total number of informants was 8 people, using interview tools. notebooks, cell phones, tape recorders, cameras, and other tools. Data collection techniques were carried out such as direct observations from researchers (Husaini Usman, 2017), interviews with the government at the Social Service, and the government in Tondegesan Satu Village (Village 
Head \& Village Secretary). Then do the documentation as evidence that the research has been carried out and to ensure the validity of the data. On this occasion the researchers used data collection techniques, data collection techniques consisted of observation (observationi), interviews (questionary) and documentation (documentary) (Husaini \& Purnomo, 2017)

\section{RESULTS AND DISCUSSION}

With a population of 490 people and 474 women. And the number of families in Tondegesan village is 292 families. Tondegesan villagers generally make a living as farmers, with a variety of good and productive natural resources such as corn, tomatoes, chilies, and others so that the people of Tondegesan village choose farming which is the main job for some people in the village of Tondelesan, as well as a small part of the people of the village of Tondelesan. choose to open small businesses at home such as selling household staples, selling food, and a small part of them are involved in the government sector (PNS), while the types of livelihoods for the people of the Tondelesan village consist of farmers, civil servants, entrepreneurs, traders, laborers Buildings, and honorary staff/teachers.

In March 2020 Corona Virus Disease 2019 entered Indonesia, and then with such a fast time the spread of Covid-19 was increasingly widespread which then attacked all provinces in Indonesia with a very significant spread which is predicted to increase the number of poor people, due to the spread of very quickly, various activities were limited to stop the spread of Covid-19, therefore the direct cash assistance program was reissued in 2020 for the community in order to reduce the burden on the poor.

In the efforts of the current Indonesian government, we all know that the spread of the 2019 Corona Virus Disease (Covid-19) has spread more significantly until now. As an effort to overcome Indonesia's national economic recovery due to the outbreak of the 2019 Corona Virus Disease (Covid-19), The government provides assistance to communities affected by Covid-19, with various existing requirements, which are regulated in the Regulation of the Minister of Villages and Development of Disadvantaged Regions and Transmigration (Permendes PDTT) number 7 of 2020 , the second amendment to the regulation of the village minister, development of disadvantaged areas, and transmigration number 11 of 2019 regarding priorities for the use of village funds in 2020 .

In Article 8A Paragraph 2, handling the impact of the Corona virus disease 2019 (Covid-19) pandemic can be in the form of Village Fund Direct Assistance (BLT-DD) to poor families in the Village in accordance with the provisions of the legislation in paragraph (3) explaining poor families 
as referred to in paragraph (2) those who receive Village Fund Direct Cash Assistance (BLT-DD) are families who have lost their livelihoods or jobs, have not been registered to receive the family hope program, non-cash food assistance, cash social assistance and pre-employment cards, and have family members susceptible to chronic/chronic illness.

To find out what the Implementation of the Village Fund Cash Direct Assistance Program Policies in the midst of the Corona virus Dessease 2019 pandemic In Tondegesan Village, is this government program to help the community in the midst of the Covid-19 pandemic, that the spread of Covid-19 causes health problems to the community which ultimately results in social and economic problems, including business actors, as well as hopes from the government that the program can help the recovery of the national economy which is experiencing uncertainty and ultimately leads to an economic recession as a result of the Covid-19 outbreak.

It is assistance from the Ministry of Social Affairs which is intended for poor families, families affected by Covid-19 such as losing their livelihoods, and families who have family members who are chronically/chronically ill in the local village, with programs designed by the Ministry of Social Affairs which are expected to reduce the impact of the 2019 Corona Dessease (Covid-19) pandemic, the value of this Village Fund Direct Cash Assistance is Rp. 600,000/Month for each BLT-DD beneficiary family who meets the existing criteria and will be given for 3 months, and then judging by the existing developments with the 2019 Corona Virus Disease outbreak, the government extends the BLT-DD program for the next 3 months by Rp.300,000 tax-free. In this study, which was conducted by the researcher himself, he interviewed several informants from the Village Consultative Body who were the implementers or it could also be said that the implementers, and then several community informants who became the families of the beneficiaries of direct cash assistance from Tondegesan village funds.

The BLT-DD program is a program from the Ministry of Social Affairs which is intended for the poor, people who do not receive other assistance such as PKH, BST and other social assistance, but the distribution of BLT-DD has not been as expected. The distribution of BLT-DD is still not appropriate, judging from the condition of the families who receive the program, families who are well-established or above the economic average also receive the assistance, but there are families who are below the average and some have not received any assistance from the government. In this case, the implementation of the direct cash assistance program for village funds has not been realized so well there is still a lot of data in determining the beneficiary families that are not in accordance with existing regulations. 
In this research, the researcher uses several indicators to see the implementation of direct cash transfers in Tondegesan village, the factors include (1) Standards and policy targets, (2) Characteristics of Implementors, (3) Policy Communication;

\section{a. Policy standards and objectives}

Van Menter and Van Horn (Subarsono, 2015) explain that policy standards and targets are what the policy or program actually wants to achieve, whether tangible or not in the short, medium or long term (Jeane, 2015). Standards relate to benchmarks or bases while goals are a description of what will be achieved. In this case, the policy that is the background for the existence of BLT-DD in the context of assistance for the underprivileged in dealing with the covid-19 pandemic, "the underprivileged" has a "standard" as stated in the regulations. Also, with the right policy standards coupled with the right policy targets, a policy will be implemented properly (Mamonto, dkk, 2020). Based on the results of the study, it was found that in determining the BLT-DD recipient families, many did not meet the requirements as recipients when viewed from the standard criteria for recipients based on regulations. Based on the researcher's search, it can be seen that there are several houses whose entrances are attached to "poor families" but the title of poor families is not reflected in the permanent concrete construction of houses, further by collecting information on the families referred to as village officials. There are also other recipient families but with the same housing situation, namely permanent concrete and having a profession as a civil servant. From the results above, it can be said that the standards that have been set for the government through Permendes No. 7 of 2020 which contains the standards for BLT-DD recipient families have not been reflected in several BLT-DD recipients in Tondegesan Village. the inclusion of "poor families" is attached but the title of poor families is not reflected in the permanent concrete construction of houses, further by collecting information on the families who are referred to as village officials.

There are also other recipient families but with the same housing situation, namely permanent concrete and having a profession as a civil servant. Based on a search by looking at the condition and condition of the house building from KPM BLT-DD it is not appropriate to receive the BLT-DD program assistance. According to a statement from NG as KPM BLT-DD that NG has been visited directly by the government and provided a card as a poor family. From the results above, it can be said that the standards that have been set for the government through Permendes No. 7 of 2020 which contains the standards for BLT-DD recipient families have not been reflected in several BLT-DD recipients in Tondegesan Village. This is reinforced by the attachment of photographs and evidence of interviews that have been poured. The ideal standard is indispensable for the success of a policy, the right standard must be accompanied by the right 
target in the field. For this reason, the first factor that influences the implementation of the Village Fund Direct Cash Assistance program policy in the midst of the 2019 Desseasi Corona virus pandemic in Tondegesan village, Kawangkoan District, is the policy standards and targets.

\section{b. Implementor Characteristics}

Van Meter and Van Horn Langkai (2015) assume that public policy runs linearly between public policy, implementor and performance of public policy implementor. One aspect that influences the success of public policy implementation is the Characteristics aspect of the Implementor (Nugroho, 2011). The researcher found that the characteristics of the implementor were related to the nature and tendency of the implementor in carrying out the policy mandate, in this case the distribution of BLT-DD. As it has been mentioned that in determining BLT-DD recipients, they must pass several stages of selection carried out in village meetings, so at that time the village government should conduct an in-depth study in order to determine the family that is in accordance with the classification referred to by the policy, in order to achieve the policy mandate. What is meant is. However, based on the results of research and information obtained, the community mentions that there are many families who are not in the category of "poor" families but are registered as recipients.

From this information, it can be seen that there are families who are forced to be included in the list of recipients while their work and income do not match. Of course, the determination of the selection of the family "not suitable as recipients" is in the hands of the implementor in this case the Village Government, so the characteristics of the implementor are very decisive for the successful implementation of a policy. This subjectivity makes many people who deserve it are not covered and their rights are replaced, the implementor of implementing the policy is a factor that influences the Implementation of the BLT-DD Assistance Policy in Tondegesan Village, Kawangkoan District

According to the first informant, $A A$, after being asked for information about the inaccurate target of BLT-DD recipients: Researchers get information Because it can be seen in the implementation that there are still many families who are categorized as capable, there is also a village apparatus who receives the assistance, while there are some poor families who have not received the assistance. , of course this is far from what the regulations say. Then the second JA informant said that in the distribution of BLT-DD, there were a lot of things that were not appropriate or not right on target, many people in Tondegesan village were not affected by COVID-19 because many jobs were still running normally, farmers who had complete agricultural assets such as tools and equipment. Large lands are even registered while farmers really need help for the survival of 
their crops such as fertilizers, plant medicines and the cost of renting a plow, even though financially it is very adequate, on the other hand there are farmers who do not have good finances and do not even get a share.

This information shows that there are families who are forced to be included in the list of recipients while their work and income do not match. Of course, the determination of the selection of the family "not suitable as recipients" is in the hands of the implementor in this case the Village Government, so the characteristics of the implementor are very decisive for the successful implementation of a policy. This subjectivity makes many people who deserve it are not covered and their rights are replaced, the implementor of implementing the policy is a factor that influences the Implementation of the BLT-DD Assistance Policy in Tondegesan Village, Kawangkoan District

\section{c. Policy Communication}

Edward III (Nugroho, 2011) suggests that communication is one of the implementation models that acts as a determinant of the success of a policy. It is further said that the implementation of a policy is a way for a policy to achieve its objectives, which implement in the form of a program or derivative of public policy. Public Policy in the form of legislation requires general guidelines or implementing guidelines (Nugroho, 2017). because the public must know how the procedures, criteria and process of channeling BLT-DD Covid-19 in order to be on target and precisely its policies in order to help the community in facing the prolonged Covid-19 pandemic. Based on information from the government community does not socialize to the community whether it is the introduction of BLT-DD, sources of funds, categories, and which families are on the list of recipients in the village of Tondegesan, suddenly the village government through the head of the guard (nutmeg) comes to the family home and asks the family ID card and KK to be registered as the recipient's family without any further review (Nurahmawati \& Hartini, 2020)

According to information from informant RP that BLT-DD has been run by the Indonesian government starting in April, May, until July in the first period that KPM Received as much as Rp.600.000, and beneficiary families in the first period as much as 89 KPM then extended to December 2020 and the amount of BLT-DD received as much as Rp.300.000, with the Beneficiary Family Mnafaat as much as $141 \mathrm{KPM}$ this program is run by the Village Government based on the policy that has been your, and in its implementation always put forward communication between the village government and the community, with the example of every decision taken starting with general deliberation. Which then for the determination of family data that is eligible to receive or not is the result of general deliberation of the village, and then conduct socialization to the community. But in fact, according to the informant TA as KPM has received direct assistance in 
cash village funds as much as 9 times from April to December, which in the first 3 months received as much as Rp.600,000 and then the next 3 months to Rp.300.000, in the stage of determination of the dasa based on the village government who directly visited the community and directly gave the BLT KPM-DD card, In the absence of any socialization at all from the government, but a lot of families who do not deserve BLT-DD, there are families who have absolutely no impact as a result of Covid-19, while there are families who deserve to get but do not get help from the central government through the village government.

From this series of information can be seen that the lack of communication makes a lack of understanding from the public about BLT-DD in the framework of covid-19, due to the lack of critical communication in response to government decisions about who is registered as a recipient. This communication factor is very influential both in terms of supporting and inhibiting the implementation of public policy in this case the BLT-DD Covid-19 Policy. This result is in line with the results found by some previous researchers related to blt policy (Direct Cash Assistance) as explained by R. Dewi, HF Andrianus in their study that the weakness of blt implementation one of which is the lack of role or participation of the community this happens because the public lacks information and knowledge about the BLT program means communication between policy providers at the lower level is less proactive in disseminating policies to the lowest communities who are beneficiaries of this program.

\section{CONCLUSIONS}

The implementation of the Covid-19 Cash Direct Assistance Program in Tondegesan Village has not been implemented properly and has not been effectively implemented due to: Standards that are not in accordance with the regulations, namely the registration of families who work as civil servants as beneficiary families and labeled poor families, when in fact the income remains the same both during the pandemic and not pandemic. Inappropriate standards and objectives between what are contained in the regulation and what is practiced make the Implementation of Direct Cash Assistance Policy of Covid 19 Village Fund in Tondegesan Village Kawangkoan Subdistrict has not been effective; Characteristics of implementors in this case the village government in determining the recipient's family is very subjective, meaning that although there are standards set in accordance with regulations, proximity to village devices greatly affects the selection of a family as a recipient. Characteristics of implementors who do not support BLT DD policy in Tondegesan village make the Implementation of Direct Cash Assistance Policy of Covid 19 Village Fund in Tondegesan Village Kawangkoan Subdistrict has not been effective; 
Communication or socialization is not done by the village government before networking anyone who is suitable family as a recipient when in the previous BLT distribution socialization is conducted. The lack of information makes the community not proactive in criticizing the decision of the list of families receiving BLT-DD as a result of the standards set by the ministry will never be achieved if there is no input in the form of criticism from the village community, especially tondegesan village against the Tondegesan village government, whereas community participation in every government decision is necessary so that the country's democratic climate is maintained and harmonious relations between village government and community will be established when communication is good, the content of the policy will be conveyed when communicated properly. Lack of policy communication makes the Implementation of Direct Cash Assistance Policy of Covid 19 Village Fund in Tondegesan Village Kawangkoan Subdistrict has not been effective.

\section{REFERENCES}

Akib, I., \&Risfaisal, R. (2015). Cash Direct Assistance. Equilibrium: Journal of Education, 3(2).

Arumdani, N., Rahmania, S. N., Nafi'ah, Z., \&Tukiman, T. (2021). Effectiveness of Direct

Assistance Cash Village Fund (BLTDD) in Mojoruntut Village, Krembung District, Kabupatensidoarjo. Indonesian Journal of Social Technology. 2(5), 874-885.

Dewi, R., \&Andrianus, H. F. (2021). Direct Assistance Policy Influence Analysis Cash (BIt) Against Poverty in Indonesia Period 2005-2015. Tower of Science. 15(2).

Finahari, R. (2017). Implementation of The Policy on Direct Cash Assistance (BLT) as Family Hope Program (PKH) In Penaga Village, Bintan Regency

Husaini, U., Purnomo, S. A. (2017). Metodologi Penelitian, Jakarta: Bumi Aksara.

Iping, B. (2020). Social protection through the Cash Direct Assistance (BLT) program policy Iqbal, H. (2008). Implementation of Cash Direct Assistance Program Policy in 2008 In Kudus Regency (Doctoral dissertation, Diponegoro University Postgraduate program). Journal of Management of Education and Social Sciences. 1 (2), 516-526.

Langkai, J. (2015). Dampak Implementasi Kebijakan Pembangunan Berbasis Lingkungan dalam Meningkatkan Kesejahteraan Masyarakat di Kota Manado.

Mamonto, F. H., Langkai, J. E., \& Mowilos, R. C. (2020). Implementasi Kebijakan Pakta Integritas di KPU Kabupaten Minahasa. Jurnal Kajian Kebijakan Dan IImu Administrasi Negara (JURNAL ADMINISTRO).

Nugroho, Riant. (2011). Public Policy. Jakarta: PT Alex Media Komputindo

Nugroho, Riant. (2017). Public Policy: Dinamika Kebijakan, Analisis Kebijakan, dan Manajemen 
Politik Kebijakan Publik. Jakarta: Elex Media Komputindo

Nurahmawati, F., \& Hartini, S. (2020). Implementation of Assistance Program Policy Direct Cash

(Blt) To People Affected by Covid-19 In Cibadak Village. PKM-P. 4(2), 160-165.

Peraturan Menteri Desa PDTT Nomor 7 tahun 2020 tentang Perubahan Kedua atas Permendesa

PDTT Nomor 11 Tahun 2019 tentang "Prioritas Penggunaan Dana Desa tahun 2020"

Peraturan Menteri Keuangan Nomor 43/PMK.05/2020 tentang Mekanisme Pelaksanaan Anggaran

Belanja atas Beban Anggaran Pendapatan dan Belanja Negara dalam Penanganan Pandemi Corona Virus Disease. 2019

Subarsono. (2015). Analisis Kebijakan Publik. Yogyakarta: Pustaka Belajar 